OPEN ACCESS

Approved by:

Neurology Editorial Office,

Frontiers, Switzerland

${ }^{*}$ Correspondence:

Frontiers Production Office production.office@frontiersin.org

Specialty section

This article was submitted to

Stroke,

a section of the journa

Frontiers in Neurology

Received: 04 December 2018 Accepted: 04 December 2018

Published: 13 December 2018

Citation:

Frontiers Production Office (2018) Erratum: Prevalence of Stroke and Hypoperfusion in Patients With Isolated Vertigo and Vascular Risk Factors. Front. Neurol. 9:1110. doi: 10.3389/fneur.2018.01110

\section{Erratum: Prevalence of Stroke and Hypoperfusion in Patients With Isolated Vertigo and Vascular Risk Factors}

\author{
Frontiers Production Office* \\ Frontiers Production Office, Frontiers, Lausanne, Switzerland
}

Keywords: vertigo, stroke, hypoperfusion, vertebral artery, basilar artery, vessel curvature

\section{An erratum on}

Prevalence of Stroke and Hypoperfusion in Patients With Isolated Vertigo and Vascular Risk Factors

by Zhang, D. P., Li, H. R., Ma, Q. K., Yin, S., Peng, Y. F., Zhang, H. L., et al. (2018). Front. Neurol. 9:974. doi: 10.3389/fneur.2018.00974

Reason for Erratum:

In the published article, there was an error in affiliation 1. Instead of "Department of Neurology, Henan University of Chinese Medicine, Zhengzhou, China," it should be "Department of Neurology, The First Affiliated Hospital of Henan University of Chinese Medicine, Zhengzhou, China."

The publisher apologizes for this error and states that this does not change the scientific conclusions of the article in any way. The original article has been updated.

Copyright $\odot 2018$ Frontiers Production Office. This is an open-access article distributed under the terms of the Creative Commons Attribution License (CC BY). The use, distribution or reproduction in other forums is permitted, provided the original author(s) and the copyright owner(s) are credited and that the original publication in this journal is cited, in accordance with accepted academic practice. No use, distribution or reproduction is permitted which does not comply with these terms. 